\title{
Correction \\ Correction: Shakil, H.; Saleem, S. Genetic Deletion of Prostacyclin IP Receptor Exacerbates Transient Global Cerebral Ischemia in Aging Mice. Brain Sci. 2013, 3, 1095-1108
}

Hania Shakil ${ }^{1}$ and Sofiyan Saleem ${ }^{2, *}$

check for

updates

Citation: Shakil, H.; Saleem, S

Correction: Shakil, H.; Saleem, S.

Genetic Deletion of Prostacyclin IP Receptor Exacerbates Transient

Global Cerebral Ischemia in Aging Mice. Brain Sci. 2013, 3, 1095-1108.

Brain Sci. 2021, 11, 624. https://

doi.org/10.3390/brainsci11050624

Received: 6 May 2021

Accepted: 7 May 2021

Published: 13 May 2021

Publisher's Note: MDPI stays neutral with regard to jurisdictional claims in published maps and institutional affiliations.

Copyright: (c) 2021 by the authors. Licensee MDPI, Basel, Switzerland. This article is an open access article distributed under the terms and conditions of the Creative Commons Attribution (CC BY) license (https:// creativecommons.org/licenses/by/ $4.0 /)$.
1 Hamdard College of Medicine and Dentistry, Hamdard University, Sharae Madinat Al-Hikmah, Karachi 74600, Pakistan; doc_hania@hotmail.com

2 Center for Neuroscience, Aging and Stem Cell Research, Sanford Burnham Medical Research Institute, La Jolla, CA 92037, USA

* Correspondence: ss1jh@yahoo.com

The authors wish to make the following corrections to this paper: ref. [1] due to identical images of p-CREB immunostaining for 2-3 months old Ischemia IP KO mice (top right panel) and 12-15 months old Ischemia WT mice (left bottom panel) in Figure 7A, replace:

A
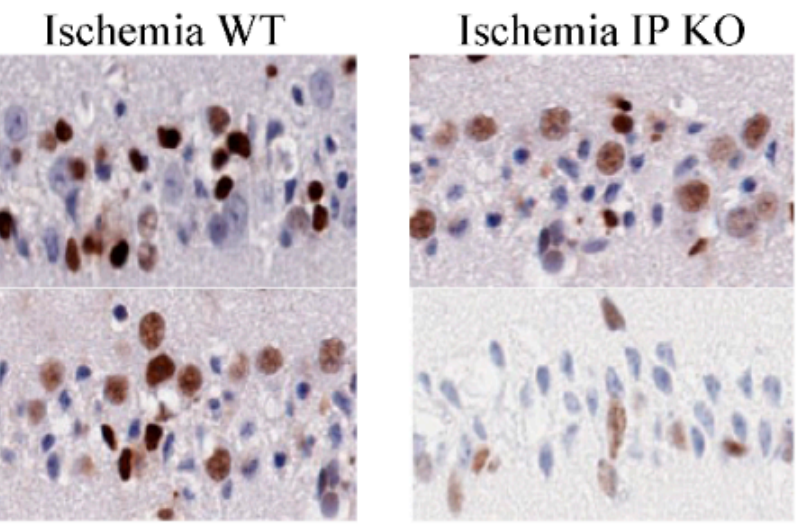

B

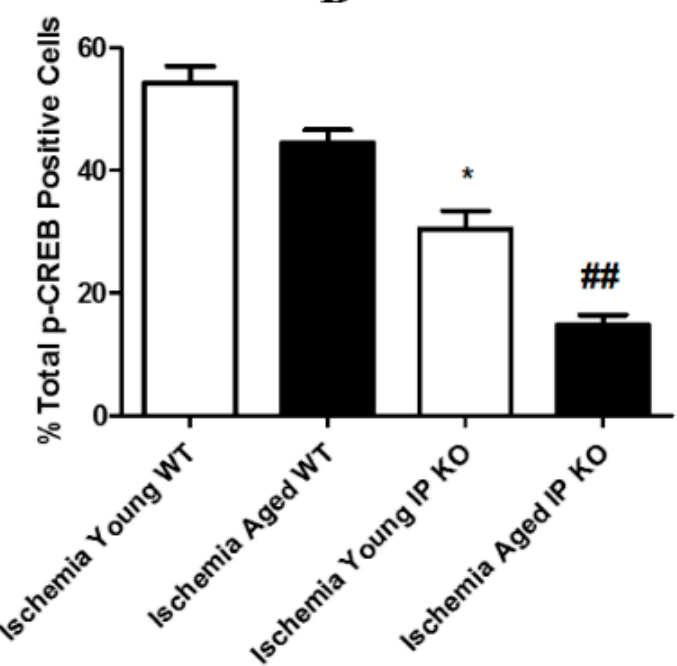

with 

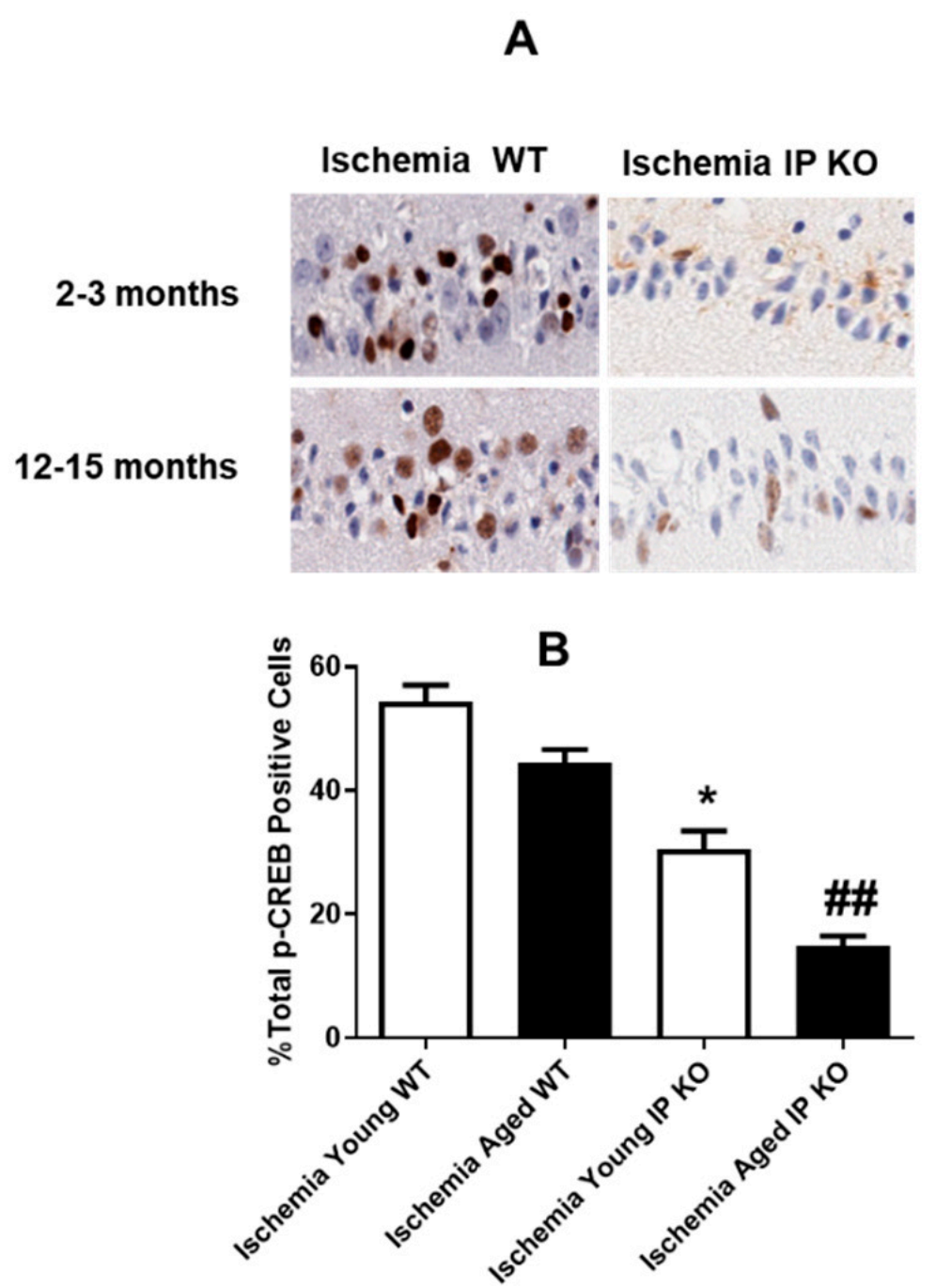

The authors would like to apologize for any inconvenience caused to the readers by these changes.

\section{Reference}

1. Shakil, H.; Saleem, S. Genetic Deletion of Prostacyclin IP Receptor Exacerbates Transient Global Cerebral Ischemia in Aging Mice. Brain Sci. 2013, 3, 1095-1108. [CrossRef] [PubMed] 